\title{
The Revision of the
}

Canadian Copyright Act: An Economic Analysis

\section{CIRANO}

Allier savoir et décision

MARCEL BOYER 


\section{$\checkmark$ CIRANO Knowledge into action}

Center for Interuniversity Research and Analysis on Organizations

The purpose of the Working Papers is to disseminate the results of research conducted by CIRANO research members in order to solicit exchanges and comments. These reports are written in the style of scientific publications. The ideas and opinions expressed in these documents are solely those of the authors.

Les cahiers de la série scientifique visent à rendre accessibles les résultats des recherches effectuées par des chercheurs membres du CIRANO afin de susciter échanges et commentaires. Ces cahiers sont rédigés dans le style des publications scientifiques et n'engagent que leurs auteurs.

CIRANO is a private non-profit organization incorporated under the Quebec Companies Act. Its infrastructure and research activities are funded through fees paid by member organizations, an infrastructure grant from the government of Quebec, and grants and research mandates obtained by its research teams.

Le CIRANO est un organisme sans but lucratif constitué en vertu de la Loi des compagnies du Québec. Le financement de son infrastructure et de ses activités de recherche provient des cotisations de ses organisations-membres, d'une subvention d'infrastructure du gouvernement du Québec, de même que des subventions et mandats obtenus par ses équipes de recherche.

\section{CIRANO Partners - Les partenaires du CIRANO}

Corporate Partners - Partenaires corporatifs

Autorité des marchés financiers

Bank of Canada

Bell Canada

BMO Financial Group

Business Development Bank of Canada

Caisse de dépôt et placement du Québec

Desjardins Group

Énergir

Hydro-Québec

Innovation, Science and Economic Development Canada

Intact Financial Corporation

Manulife Canada

Ministère de l'Économie, de la Science et de l'Innovation

Ministère des finances du Québec

National Bank of Canada

Power Corporation of Canada

PSP Investments

Rio Tinto

Ville de Montréal

Academic Partners - Partenaires universitaires

Concordia University

École de technologie supérieure

École nationale d'administration publique

HEC Montréal

McGill University

National Institute for Scientific Research

Polytechnique Montréal

Université de Montréal

Université de Sherbrooke

Université du Québec

Université du Québec à Montréal

Université Laval

CIRANO collaborates with many centers and university research chairs; list available on its website. Le CIRANO collabore avec de nombreux centres et chaires de recherche universitaires dont on peut consulter la liste sur son site web.

(C) December 2020. Marcel Boyer. All rights reserved. Tous droits réservés. Short sections may be quoted without explicit permission, if full credit, including (C) notice, is given to the source. Reproduction partielle permise avec citation du document source, incluant la notice (C).

The observations and viewpoints expressed in this publication are the sole responsibility of the authors; they do not necessarily represent the positions of CIRANO or its partners. Les idées et les opinions émises dans cette publication sont sous l'unique responsabilité des auteurs et ne représentent pas nécessairement les positions du CIRANO ou de ses partenaires. 


\title{
The Revision of the Canadian Copyright Act: An Economic Analysis
}

\author{
Marcel Boyer +
}

\begin{abstract}
Résumé
A clause of the 2012 Canadian Copyright Modernization Act requires Parliament to review the Copyright Act every five years. The House of Commons instructed two of its committees, the Standing Committee on Industry, Science and Technology (INDU) and the Standing Committee on Canadian Heritage (SCCH), to review the Copyright Act. The committees filed their reports in 2019. Four of their recommendations are particularly relevant and discussed here: the extension of the term of copyright, the introduction of a so-called "termination right", an amendment of the copyright reversion regime, and the introduction of a mandatory registration. My study is intended to inform policy analysis of these recommendations, including, among other things, the upfront impact on creator bargaining power and remuneration; the long-term impact on a work's availability and potential revenues; the creative marketplace in general; and the interactions between the proposed legislative amendments and other areas of the Copyright Act.
\end{abstract}

Keywords/Mots-clés: Copyright Term Extension, Copyright Termination Right, Copyright Reversion Regime, Creators Remuneration, Bargaining Power, Risk and Discounting

\footnotetext{
* December 21, 2020. Revised January 4, 2021.

${ }^{\dagger}$ Ph.D., O.C., FRSC. Emeritus Professor of Economics, Université de Montréal; Bell Canada Professor of Industrial Economics (2000-2008), Université de Montréal; Jarislowsky-SSHRC-NSERC Professor of International Competition (1993-2000), École Polytechnique de Montréal; Associate Member, TSE and IAST; Fellow, CIRANO and C.D. Howe Institute.

$¥$ I am grateful to the numerous economists and lawyers from academia, copyright collectives, law firms, private and public organizations and corporations, judges on copyright boards, in Canada and abroad, representing all sides of cases and debates, sometimes highly charged, for their generous comments and lessons, examinations and cross examinations, which have helped forge my understanding of copyright issues over the last decades. They are too numerous to list here. Needless to say, I remain solely responsible for the content of this paper, in particular of its shortcomings.
} 


\section{TABLE OF CONTENT}

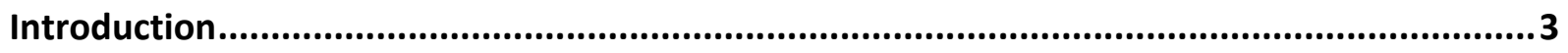

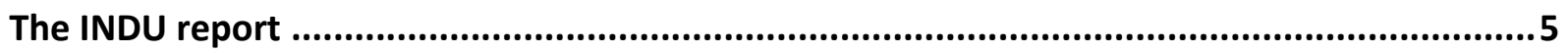

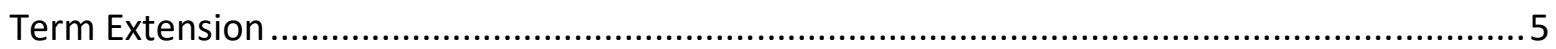

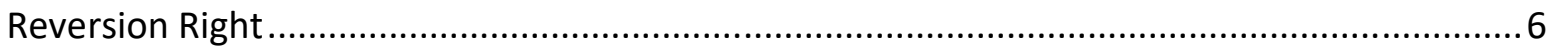

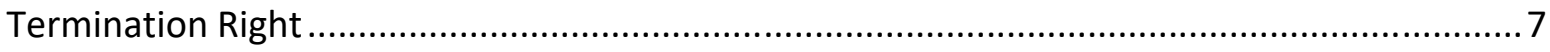

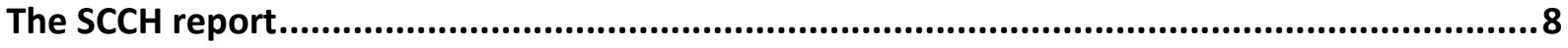

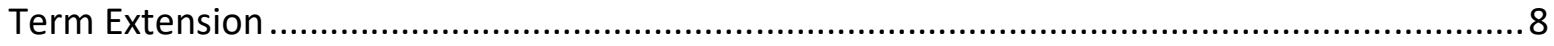

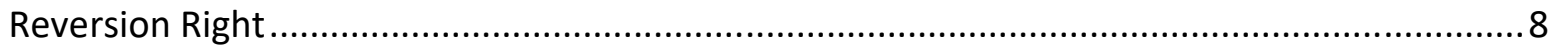

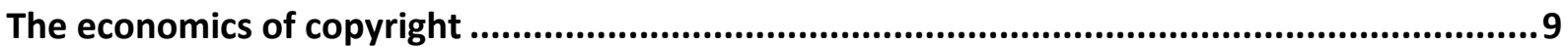

Why Does Copyright Pose Such A Difficult Economic Problem? ............................................. 10

Key Relevant Concepts to Understanding the Impact of the Recommendations .................11

A critical review of the recommendation to implement term extension ..............................13

Term extension sets the condition for the proper price-setting mechanism to emerge .........13

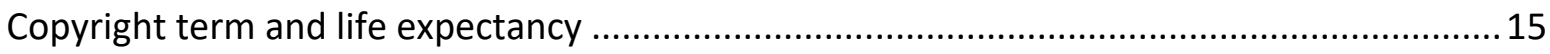

The economics of discounting and of post-creation changing of rules/regulations.................16

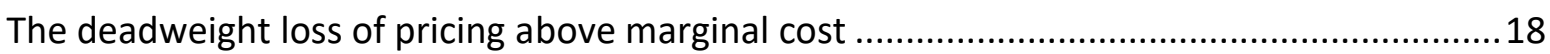

A critical review of the reversion and termination rights recommendations...........................18

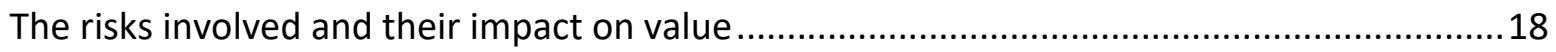

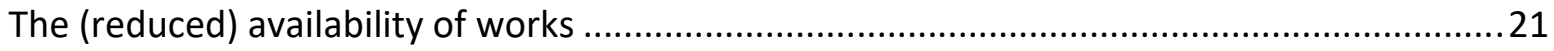

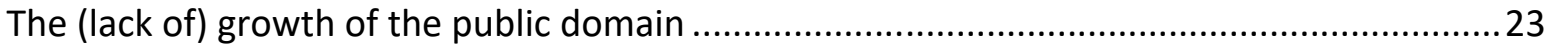

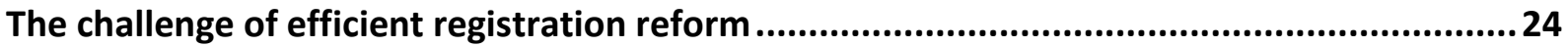

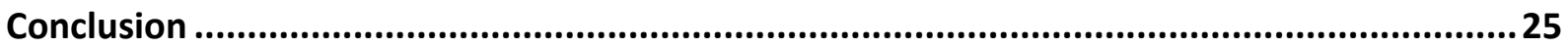

APPENDIX A. The economics of copyright: a difficult economic problem ...............................26

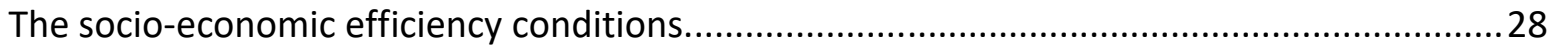

Creators' compensation: The size of the pie and the sharing of the pie................................31

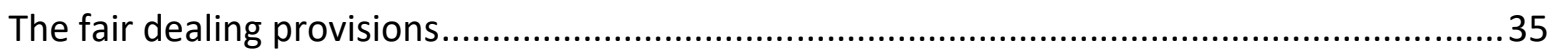

APPENDIX B. Eldred (Us Supreme Court): Comments on Justices Ginsburg and Breyer ...........38

APPENDIX C. Additional misconceptions about term extension .........................................40 


\section{Introduction}

On December 14, 2017, the Minister of Innovation, Science and Economic Development Canada and the Minister of Canadian Heritage announced plans to commence a parliamentary review of the Copyright Act.

The Canadian House of Commons Standing Committee on Industry, Science and Technology (INDU) was entrusted with the parliamentary review. INDU received 192 written briefs and heard testimony from 263 witnesses. ${ }^{1}$ On June 3, 2019, the INDU report was released. The INDU report includes 36 recommendations and discusses, among other things, term extension, the reversion right, and a termination right. ${ }^{2}$

The Canadian House of Commons Standing Committee on Canadian Heritage (SCCH) was asked, as part of the parliamentary review, to conduct a parallel consultation. On April 10, 2018, $\mathrm{SCCH}$ announced its launch of a Study on Remuneration Models for Artists and Creative Industries in the Context of Copyright. SCCH received 75 briefs and heard testimony from 115 witnesses. On May 15, 2019, the SCCH report entitled "Shifting Paradigms" was released. ${ }^{3}$ The $\mathrm{SCCH}$ report includes 22 recommendations and discusses, among other things, term extension and the reversion right.

In Canada, the term of copyright lasts from the time of creation until the end of the calendar year that is 50 years after the death of the creator. ${ }^{4}$ The duration of the general term of copyright in Canada is shorter than in most of its main economic partners (see Figure 1 of INDU Report). And Section 14 of the Copyright Act returns copyright to an author's heirs 25 years after his/her death, deeming void the terms of any contract assigning copyright or granting an interest in his/her copyrighted works. Section 14 thereby provides the author's heirs a possibility to reassess the value of the deceased author's copyrights and strike a new contract if the observed value justifies a renegotiation of contract terms.

The following four recommendations made by the committees are particularly significant:

\footnotetext{
${ }^{1}$ Submissions were received from a wide variety of stakeholders, including individuals, student associations, universities, libraries and researchers; unions, associations and collective management organizations representing creators and performers; corporations from the communications sector; associations representing the film, theatre and music industries; media organizations; government departments; and representatives of the Copyright Board of Canada.

${ }^{2}$ Statutory Review of the Copyright Act: Report of the Standing Committee on Industry, Science and Technology. $42^{\text {nd }}$ Parliament, $1^{\text {st }}$ Session (June 2019). Available online at https://www.ourcommons.ca/Content/Committee/421/INDU/Reports/RP10537003/indurp16/indurp16-e.pdf ${ }^{3}$ Shifting Paradigms: Report of the Standing Committee on Canadian Heritage. $42^{\text {nd }}$ Parliament, ${ }^{\text {st }}$ Session (May 2019). Available online at https://www.ourcommons.ca/Content/Committee/421/CHPC/Reports/RP10481650/chpcrp19/chpcrp19-e.pdf

${ }^{4}$ In the case of a published sound recording or performer's performance, copyright subsists for 70 years from the end of the calendar year in which the first publication occurs (or 100 years from the date of the first fixation of the performer's performance or sound recording, if earlier).
} 
1. The extension of the term of copyright from the life of the author plus 50 years to the life of the author plus 70 years, conditional on the ratification of the Canada-United StatesMexico Agreement (CUSMA) (INDU).

2. The introduction of a so-called "termination right", that is, a "non-assignable right to terminate any transfer of an exclusive right no earlier than 25 years after the execution of the transfer" (INDU).

3. The proposed amendment of the copyright reversion regime to make it effective 25 years after the execution of the transfer, rather than 25 years after the death of the author $(\mathrm{SCCH})$.

4. The introduction of registration as a mandatory prerequisite for the enforcement of the exclusive rights of a copyright owner during the 20-year extension term, as well as for the exercise of the reversion right and the proposed termination right.

My objective in this paper is to inform the policy analysis of these recommendations, including, among other things, the upfront impact on creator bargaining power and remuneration; the longterm impact on a work's availability and potential revenues; the creative marketplace in general; and the interactions between the proposed legislative amendments and other areas of the Copyright Act.

The main issues underlying the reports and recommendations of the INDU and SCCH Committees are twofold. First, to increase the compensation of creators of copyrighted works, which they considered too low, the Committees recommended a copyright term extension to life plus 70, a modification of the reversion right, and the introduction of a termination right to increase the creators' negotiating power in the sharing of royalties. Second, in order to mitigate certain perceived impacts of term extension, reversion, and termination, they recommended the introduction of mandatory registration conditions.

I first review the Committees' reports relevant to my mandate before developing a critical economic review of the arguments underlying their recommendations. I explain that INDU and SCCH's observations and recommendations demonstrate that at least four basic relevant concepts have so far been misunderstood or overlooked. Later, I explain the economic implications of those gaps and consider whether the proposed amendments favour or improve the processes that govern the production and dissemination of copyright-protected works.

In my economic analysis, I insist on considering the copyright world as a complex ecosystem with intertwined incentives, and I caution against creating artificial conflicts between creators and creative businesses, who are in a joint endeavour to maximize the value of creations.

I also insist on the distinction between the "size of the pie" (future expected royalties discounted at a risk-adjusted discount rate) and the "sharing of the pie" between creators and other 
stakeholders including creative businesses. I argue that the Committees concentrated their efforts on factors that may affect the sharing of the pie. In so doing, the Committees' recommendations may result in creators capturing a larger share of a smaller pie, resulting in overall lower compensation to creators. If the Committees' goal was to increase the compensation of creators of copyrighted works, they should have invested more effort on factors that affect the size of the pie.

I analyze the most common arguments against copyright term extension. I show that the power of these arguments is significantly reduced when a more holistic approach is taken that challenges assumptions about the incentive effects of economic discounting and that insists on the shared economic efficiency goals of creators and creative businesses.

I explore the impact of the Committees' recommendations regarding reversion rights and termination rights. I argue that modifying the reversion right and introducing a termination right may favor an increase in royalty risks, thereby depressing their discounted value.

I critique and refute other common misconceptions about term extension, reversion rights and termination rights, most notably that term extension prevents the growth of the public domain and that weaker reversion or termination rights lead to reduced availability of works.

I argue that the strongest economic argument against registration is that it significantly raises transaction costs and introduces significant uncertainty in the system.

I conclude that term extension favours an increase in future royalties and is fully compatible with economic efficiency principles. I also conclude that the most probable effect of the increased uncertainty arising from a redefined reversion right and the introduction of a new termination right may reduce the size of the royalty pie and hurt the creators they were intended to help.

\section{The INDU report}

The following section summarizes INDU's observations and recommendations regarding term extension, the reversion right, and a termination right. ${ }^{5}$

\section{Term Extension}

Several witnesses supported extending the term of copyright, arguing that it would increase opportunities to monetize copyrighted content, and thus increase the value of copyright holdings and encourage investments in the creation, acquisition, and commercialization of existing and future copyrighted content, while also harmonizing the Copyright Act with that of major trading partners, as well as benefitting a deceased author's descendants (providing they hold copyright).

\footnotetext{
${ }^{5}$ See pages 32-39 of the INDU report for a more fulsome review of the evidence it considered and its observations.
} 
Several other witnesses opposed extending the term of copyright, predicting it would worsen the problem of orphan works and make it hard to access, build on, disseminate, and preserve works, that the term of copyright was already enough time for rights holders to profit from copyrighted content, and that term extension would enrich intermediaries and not creators. Some witnesses suggested that mitigation efforts, such as subjecting copyright protection for an extra 20 years to formalities, such as registration, would comply with international obligations, promote copyright registration, and help lessen the orphan work problem.

INDU observed that if the current version of CUSMA is ratified, Parliament would need to make the Copyright Act compliant with the new agreement by extending copyright from 50 to 70 years after the death of the author of a work.

INDU favoured extending the term of copyright, but only if CUSMA is ratified. INDU stated that it expects that rights holders will benefit from term extension, but also noted the arguments made against it. INDU believed that requiring rights holders to register their copyright to enjoy its benefits after a period equal to the life of the author plus 50 years would mitigate some of the perceived disadvantages of term extension, promote copyright registration, and thus increase the overall transparency of the copyright system.

It therefore recommended:

\section{INDU Recommendation 6}

That, in the event that the term of copyright is extended, the Government of Canada consider amending the Copyright Act to ensure that copyright in a work cannot be enforced beyond the current term unless the alleged infringement occurred after the registration of the work.

\section{Reversion Right}

Some witnesses proposed eliminating the reversion mechanism in the Copyright Act because it significantly increases the uncertainty of copyright transfers with little benefit to creators and their descendants and may instead hinder the commercial exploitation of the copyrighted content. Other witnesses argued that American copyright legislation provides a termination right to the benefit of creators and that there is quite a lot of investment taking place in that sector. INDU noted that many witnesses in favour of term extension said virtually nothing against the reversion mechanism, suggesting that the actual impact of reversion on business practices remains limited.

INDU observed that many witnesses supported term extension to increase the revenues of the descendants of the author and that, as a result, it would be counterproductive to repeal section 14 
of the Copyright Act. INDU stated that the provision could be amended to increase the predictability of the reversion mechanism.

It therefore recommended:

\section{INDU Recommendation 7}

That the Government of Canada introduce legislation amending the Copyright Act to provide that a reversion of copyright under section 14(1) of the Act cannot take effect earlier than 10 years following the registration of a notification to exercise the reversion.

\section{Termination Right}

A termination right was proposed to "ensure that more of the benefits from copyright extension flow to creators", as well as to address the "bargaining imbalance" between creators and other members of creative industries, to, among other things, grant creators the opportunity to resell their copyright with better knowledge of its market value 25 years after its assignment. Others argued that termination rights were not necessary because the Copyright Act can already accommodate such an arrangement in the assignment contract and that the preferred solution would be to introduce amendments that would increase the revenues of all rights holders who can then determine how to share such revenues.

INDU observed that creators already "receive little remuneration for their work", the effective lifespan of most copyrighted content tends to be short, and that the U.S. experience does not suggest that the termination right deters investment. INDU concluded that, "if copyrighted content is still commercially profitable 25 years after being created, its creator should have the opportunity to increase the revenues they draw from it. The Government, should, however, take measures to make the exercise of the termination right predictable."

It therefore recommended:

\section{INDU Recommendation 8}

That the Government of Canada introduce legislation amending the Copyright Act to provide creators a non-assignable right to terminate any transfer of an exclusive right no earlier than 25 years after the execution of the transfer, and that this termination right extinguish itself five years after it becomes available, take effect only five years after the creator notifies their intent to exercise the right, and that the notice be subject to registration. 


\section{The SCCH report}

The following section summarizes the views heard by the SCCH and its recommendations regarding term extension and the reversion right. ${ }^{6} \mathrm{SCCH}$ did not discuss a termination right.

\section{Term Extension}

Witnesses proposed to extend the term of copyright protection to align with Canada's main international partners. SCCH acknowledged that CUSMA, though it had not completed the legislative process towards ratification and implementation, requires Canada to modify its intellectual property framework to extend copyright protection to "life plus 70 years."

Witnesses stated, among other things, that the length of the copyright term was meant to protect creators for two generations, that term extension would mean additional investment "in the career development of Canadian songwriters and composers", that it would give creators "the ability to leverage their success", and that aligning Canada's copyright term with its major trading partners would ensure "robust compensation" to creators and their families.

No witnesses expressed outright opposition to term extension, but one witness brought forward a "nuanced approach" that there is "no incentive up front to artists to extend term to 70 years after death" and that there is more value in rights reversion. She concluded that "reversion and ownership of rights do not exclude actual term extension."

SCCH recommended:

\section{SCCH Recommendation 7}

That the Government of Canada pursue its commitment to implement the extension of copyright from 50 to 70 years after the author's death. ${ }^{7}$

\section{Reversion Right}

Witnesses recommended a modification to the rights of reversion provision, replacing "death of the author" in ss. 14(1) of the Copyright Act with the word "assignment." Witnesses stated that would "limit the unfairness" that comes from unequal bargaining position of creators and that "rights reversion" offers a real incentive to creators compared to term extension by giving them an opportunity to obtain greater benefit from works that may continue to have a market.

\footnotetext{
${ }^{6}$ See pages 21-22 and 30-31 of the SCCH report for a more fulsome review of the evidence it heard.

${ }^{7}$ Unlike INDU, SCCH did not propose any registration requirement tied to the extension of term.
} 
SCCH recommended: ${ }^{8}$

\section{SCCH Recommendation 14}

That the Government of Canada amend subsection 14(1) of the Copyright Act so that it reads "from 25 years after assignment."

\section{The economics of copyright}

The objectives underlying the INDU and SCCH recommendations appear to be twofold:

1. To address the so-called imbalance in creators' bargaining power to help creators secure additional compensation; ${ }^{9}$ and

2. To mitigate the effects of, or increase predictability in relation to, term extension, reversion, and termination, by introducing a registration requirement. ${ }^{10}$

As I explain, it is extremely difficult to assess the so-called economic impact of different changes in copyright laws on different groups of stakeholders. The efficiency conditions of the production and dissemination of copyright-protected works are more complex than for ordinary goods.

Rather than attempt to quantify the impact of term extension, reversion rights, or termination rights on these different groups, I take a more meaningful approach to consider whether the proposed amendments favour or improve the processes that govern the production and dissemination of copyright-protected works. If they do, it would suggest that the amendments are warranted. If they do not, it would suggest that the amendments should be reconsidered or dropped altogether. For reasons discussed below, I conclude that the proposed amendments are unlikely to encourage the production and dissemination of copyright-protected works, and may actually discourage them.

Before engaging in that analysis, I discuss how some of INDU and SCCH's observations and recommendations seem to overlook or misunderstand certain key underpinnings of the copyright eco-system. I posit that, had those considerations been properly understood, they may have led to

\footnotetext{
${ }^{8}$ Unlike INDU, SCCH did not propose any notification requirement or other prerequisite to the exercise of the reversion of copyright.

${ }^{9}$ This first element rests on the often-repeated observation that creators "receive little remuneration for their work." This observation appears to be the fundamental underpinning of the recommendations regarding the term extension of copyright, the proposed amended rights reversion provision, and the introduction of a new termination right.

${ }^{10}$ The second element seems to rest on the belief that expanding the existing registration system can be done at minimal cost and that the system could thereafter run efficiently, as well as the belief that term extension should be tempered in some way. See the section on "The challenge of registration reform" for more on this.
} 
different observations and recommendations. ${ }^{11}$ I then consider whether the proposed amendments favour or improve the processes that govern the production and dissemination of copyright-protected works.

\section{Why Does Copyright Pose Such A Difficult Economic Problem?}

The economics of copyright are not a simple application of basic or elementary economic principles. ${ }^{12}$ They engage rather advanced concepts and analysis in economic theory, described in more detail at Appendix "A".

Generally, copyrighted works are information goods, ${ }^{13}$ which pose significant and difficult problems in economic analysis.

An information good is a product or service whose value arises from the information it contains. Once produced, at a relatively large fixed cost, it can be reproduced or consumed by all at a low to zero marginal cost. Books, musical works, and sound recordings are all examples of information goods, or "non-rival goods": once created, they can be consumed by everyone. In contrast, a "rival good" - a tomato, for example - can only be consumed once; once consumed, that same tomato cannot be consumed by anyone else.

A rival good can be valued by obtaining an estimate of the marginal cost and the marginal willingness of consumers to pay. The same analysis can be applied to information goods, but

\footnotetext{
${ }^{11}$ Of course, INDU and SCCH cannot be faulted entirely, having based its recommendations on the evidence of various stakeholders that was not based in economic theory or in some cases, the full reality of the copyright ecosystem in which negotiations and bargains take place.

${ }^{12}$ An example of a poorly reasoned inflammatory statement is provided by Matt Ridley, the award-winning writer and blogger (and one of my favourites), in his recent book How Innovation Works (HarperCollins, 2020). Ridley writes: "The whole purpose of new ideas is to share them and allow them to be copied... All in all, the evidence that patents and copyrights are necessary for innovation, let alone good for it, is weak. There is simply no sign of a 'market failure' in innovation waiting to be rectified by intellectual property, while there is ample evidence that patents and copyrights are actively hindering innovation.' He continues: 'Online file sharing in the music industry, after a brief battle, established itself without killing the music industry: performers went back to performing live to make money, rather than sitting back and letting the royalties roll in." This is really the ultimate condescending comment. What about the author of the lyrics? The music composer? Curiously, Ridley's book is copyrighted, allowing it to be sold at a good price, that is, good for the author not for the intended reader! Maybe the book should not have been copyrighted, but freely printed and distributed at a cheap price, with Ridley himself going on the road to give lectures and conferences "to make money, rather than sitting back and letting the royalties roll in." An otherwise great book, but significantly damaged by some poorly reasoned pages on intellectual property.

${ }^{13}$ For simplicity, I use the term "information goods" to capture both "information goods" and "information assets". While otherwise similar, durability distinguishes the concepts. An information good is typically available for a short period or only at the time it is produced, while an information asset is available for an indefinite period. Once created, an information asset can be consumed by everyone now and in the future. Accordingly, while copyrighted works may be more accurately referred to as "information assets", I use the term "information goods" for simplicity and consistency.
} 
with an added challenge: which marginal cost to use? The marginal cost of reproducing an information good (low) or the marginal cost of creating such information good (high)?

The first-best social efficiency rule calls for selling the good at its marginal cost and covering the deficit through, for example, a government subsidy. However, this would likely be unrealistic and subject to political cronyism and other bureaucratic imperfections. Economists have proposed a different rule, which they called the second-best, as different from the first-best, efficiency rule, which would set the price of copyrighted works above their marginal reproduction cost in such a way that pricing generates enough revenues to properly compensate creators while ensuring the largest and widest possible dissemination. This rule generates some deadweight loss, as the price is set above the marginal cost of reproduction, but it avoids relying on bureaucracy or a potentially fickle political calculus. This is where our attention should lie.

The balancing act here is to provide proper incentives for creators and innovators while at the same time fostering the dissemination of creations and innovations: proper incentives and proper dissemination rest fundamentally on the competitive market evaluations of value, costs, and benefits. To make that assessment, an evidence-based research program into the three essential facets of compensation would be required: determining the size of the pie, the contributors or payers into the pie, and how that pie should be shared.

\section{Key Relevant Concepts to Understanding the Impact of the Recommendations}

INDU and SCCH's observations and recommendations demonstrate that at least four basic relevant concepts have so far been misunderstood or overlooked. Later in my report, I explain the ensuing economic implications.

First, contracts under the current Copyright Act can already accommodate the types of "arrangements" the Committees recommended. The amendments proposed are unlikely to deliver any real benefit to creators if imposed on them and their creative business partners. By superficially micromanaging the relationships between creators and creative businesses through legislative amendments, the changes are likely to end up doing more harm than good to creators and reduce their overall compensation, as I discuss in more detail below.

The Committees did not appear to appreciate that any change in the way copyright will be managed in the future will have impacts today: restrictions on term extension, amendments to the reversion right, and the introduction of a termination right, reduce the value of copyrighted works for creative businesses (producers, record labels, publishers, distributors, and others) and therefore the value of payments to creators, upfront now or over time. ${ }^{14}$

\footnotetext{
${ }^{14}$ In contrast, increasing the length during which they will be able to exploit the works and reducing the uncertainty of ownership itself will necessarily induce creative support companies, assignees, and licensees to increase the
} 
To illustrate this point, copyright industries can be viewed as forming a microcosm or an ecosystem that consist in a complex set of nodes/neurons (with creators and creative businesses at the forefront) and their interconnections (relations and contracts). Creators and creative businesses are involved in a joint endeavor to maximize the value of creations, including the development and promotion of artistic talent. It is important not to create an artificial conflict between the groups. Intervening in that ecosystem in a poorly informed and poorly coordinated way is very much like acting as a bull in a china shop.

Second, although the Committees heard from many stakeholders that, in general, creators receive (too) little remuneration for their work, any suggested correction to the underlying factors must, as I argue, take into account the determinants of market value of creations, the mathematics of discounting the future, and the presence of uncertainty.

The Committees' recommendations deal exclusively with regulating the downstream game of sharing royalties between creators and other stakeholders, particularly creative businesses, without modifying the upstream game of the way royalties for copyrights are determined and the amount of royalties paid by users "at large." This is equivalent to pursuing the wrong objective; to lose sight of the forest for the trees. It is important not to create artificial conflicts among partners in the development and promotion of creations. In a real sense, creators and creative businesses are in the same boat; without addressing the upstream game at the same time as the downstream game, creators will ultimately lose instead of gain compensation.

The Committees fail to recognize that the incentive for creators to create innovative, highquality works, on the one hand, and the incentive for creative businesses to maintain the availability of works, develop and promote their market value, and protect them from decaying and falling into oblivion, on the other hand, are inextricably intertwined. ${ }^{15}$ The Committees should have proposed amendments to the Copyright Act that could and would increase the "size of the pie" by raising the revenues of all rightsholders and their partners towards their competitive levels. Instead, they engage in the "sharing of the pie," taking from creative businesses to try to give more to creators, ultimately reducing the pie.

Third, to introduce a series of impediments to the smooth unraveling of copyright term extension, including mandatory registration or a new termination right, risks making the updated Copyright Act even more cumbersome and opaque than the current one, with significant new transaction costs and few if any corresponding benefits.

discounted expected value of a copyright transfer and therefore increase the competitive amount they will pay upfront now or later to a creator.

${ }^{15}$ Indeed, investment in songwriter development as well as more generally talent development across the copyright industries is a major factor in the success of creators, and these investments rest in good part on copyright revenues allocated to creation support companies. See, e.g., Lisa Freeman (2017), Export Ready, Export Critical: Music Publishing in Canada, Canadian Music Publishers Association, July 31 (Appendix with Benoit Gauthier of CIRCUM). 
Fourth, in Canada, there is an explicit recognition of creators' rights and users' rights being on an equal footing. The competitive pricing of copyrights in such a context aims to achieve both balance and neutrality between creators' rights and users' rights. Achieving such pricing and equilibrium requires a move away from traditional heuristics toward sounder analytics.

Unfortunately, INDU and SCCH did not venture in any serious way into those difficult issues.

\section{A critical review of the recommendation to implement term extension}

Many of Canada's global trading partners have already implemented term extension.

In 1995, the European Union extended the term of copyright for its member states to the life of the author plus 70 years. The change was a consequence of a Directive of the European Commission in 1993, which required member states to increase their basic term of protection. Ostensibly, the purpose of the Directive was to harmonise the laws of European Union members, as national laws ranged from between life plus 50 years to life plus 70 years. Consistent with the Berne Convention, the EU permitted its members to deny this longer term to the works of any non-EU country whose laws did not secure the same extended term.

In the U.S., the term extension of copyright from life plus 50 to life plus 70 was enacted following the US Copyright Term Extension Act of 1998 ("CTEA"), also known as the Sonny Bono Copyright Term Extension Act. The CTEA was the object of a lengthy court battle culminating in the 2003 decision of the US Supreme Court in Eldred v. Ashcroft. ${ }^{16}$ In that case, an electronic publisher, Eric Eldred, was concerned that the 20-year extension in the copyright term would prevent him from publishing books that had been previously in the public domain. I briefly review this case in Appendix "B" and comment on the main arguments from Justice Ginsburg (for the majority) and Justice Breyer (for the dissent) in that decision.

The INDU and SCCH reports refer to arguments like the ones raised in the Eldred case, which have been put forward by different stakeholders.

\section{Term extension sets the condition for the proper price-setting mechanism to emerge}

Let us insist at the outset that copyright term extension does not prevent publication and does not prevent the use of creative works. Instead, it sets the condition for a proper price-setting mechanism to emerge.

Having access to past copyrighted material in the creation process of current creators is not much different from having access to office space, equipment, plumbers, electricians, managing consultants, artistic consultants, and so on. All of those resources or factors help creators produce new quality works. The fact that creators must pay for those factors necessarily limits their capacity to produce more works. But, nobody claims that creators should not be asked to pay

16537 U.S. $186(2003)$. 
their rent or electricity simply because they are creators. The royalties to be paid for the use of copyrighted works from the past is no different.

Furthermore, all those payments for factors in the creative processes are nothing to worry about, insofar as such payments, including royalties, are set or determined by competitive forces. Clearly, there are numerous copyrighted works from the past that are competing with each other in such an intense way that royalties can be considered competitive.

Most stakeholders recognize the benefits of copyright law in terms of inducing creation, allowing the maintenance, promotion, and marketing of copyrighted works, and more generally favouring the advancement of arts, culture, and science. Most stakeholders also recognize the impediments that adding 20 years of copyright protection may create for artistic and cultural development as well as for scientific activities, in particular for teaching and research. But again, that is not very different from impediments created by the necessity to use other costly factors, goods and services in the creation of new works as well as in teaching and research. And there are benefits too.

Opponents of term extension argue that it adds little, if any, incentive for creation. They argue that, although term extensions may favour maintenance and marketing of works by copyright owners (some individuals but mainly organizations and creative businesses), such maintenance and marketing could be better achieved at lower costs, especially by reducing the cost of identifying and finding the copyright owner(s) in many cases, by letting the works in question fall into the public domain, and letting artistic and cultural associations as well as public library archivists take care of them. They maintain that the beneficiaries of term extension are therefore not the creators themselves but rather corporations and creative businesses.

The fallacy in this argument is that it overlooks that creative businesses obtain copyrights from the creators through a willing buyer/willing seller relationship. Therefore, the fact that copyrights are protected (even if the copyright owner is a creative business) allows individual creators to receive better compensation for their works. It is the very foundation of the institution of copyright itself. It is similar for trademarks: when corporations are protected against the improper use of their trademarks, the ultimate benefactors are their employees and other stakeholders as well as the general public. Moreover, it allows creative businesses to support the development of new works by contemporary artists.

Opponents of term extension portray it as a victory for corporate control of cultural heritage through the inhibition of dissemination of cultural works through new technologies, sometimes framed as an economic policy of intellectual property, that is, "a conceptual map of issues, a rough working model of costs and benefits." ${ }^{17}$ But again, these arguments are aimed at the wrong

${ }^{17}$ See for instance Matthew Rimmer (2003), "The dead poets society: The copyright term and the public domain", First Monday 8(6), 2 June 2003. https://firstmonday.org/ojs/index.php/fm/article/download/1059/979 
target, namely the pursuit of the availability and use of works not for free but free from royalties, rather than the more reasonable objective of maximizing availability and use and favoring the creation of new works by contemporary creators, under the constraint of proper compensation for rightsholders.

For most stakeholders, the benefits of an "early public domain" arrangement are minimal, if they exist at all. Experience suggests that the key beneficiaries of expired copyrights are businesses that seek to profit from distributing public domain works. However, they do so at a cost that is only somewhat lower than what those works would command if still protected by copyright. ${ }^{18}$ It is not apparent that there are any real benefits to the public at large. What is perfectly clear, however, is that creators receive no compensation from the repackaging and distribution of public domain works. And even if it is true that such additional compensation would add little incentive for the creators of the works, it does not mean that it is irrelevant.

What is at issue is the fine balance in copyright between the relative virtues of rights and remuneration, on the one hand, and of the public interest in wide dissemination, on the other hand. Copyright law should strive to avoid creating artificial conflict between creators and their partners, namely creative businesses, in the objective of a second-best efficient solution: maximizing the availability and use of copyrighted works under the constraint of a fair and equitable (i.e. competitive) compensation of creators. ${ }^{19}$ Therefore, it is misleading from an economic perspective to view postponing the expiration of copyrights by 20 years as inevitably harming the public interest. At most, it simply sets the stage for a price-setting mechanism to emerge in relation to the use of older works during that 20 -year period.

\section{Copyright term and life expectancy}

An increase in the copyright term may be justified by the fact that life expectancy has increased significantly. If it was reasonable to have a 50-year post-mortem term in the past when life expectancy was shorter than today, it may be justifiable to have a longer copyright term as life expectancy has increased: ${ }^{20}$ "The term of protection currently afforded by our Copyright Act is

\footnotetext{
${ }^{18}$ See for instance Stargrove Entertainment Inc. v. Universal Music Publishing Group Canada et al., 2015 Comp. Trib. 26, in which an upstart record label sought leave to commence an action under the Competition Act against various record labels, music publishers, and collective societies for allegedly conspiring not to grant mechanical licences for the reproduction of musical works on bargain-basement compilation CDs consisting of popular sound recordings that had recently fallen into the public domain.

${ }^{19}$ As Barker (2015) puts it: "A further problem with the work cited by critics of copyright term extension for sound recordings is that it has failed to recognize that music companies use current income to invest in new artists, and why this is rational behaviour. Record companies tend to be better judges of returns on investment in current music than outside investors. This means internal financing out of current income, rather than external financing, is at a lower cost. Thus, increased revenues from older works under an extended copyright term will be used by music companies to expand investment into new sound recordings and in the development of new and existing artists." ${ }^{20}$ Canada joined the Berne Convention in 1928, which coincided with the adoption of the life plus 50 requirement. At that time, the average life expectancy for Canadians was about 60 years. By 2009, it had risen to about 81 years.
} 
out of step with the goals of the Berne Convention: it is insufficient to cover two generations of descendants of a songwriter." 21

More importantly, the incentives to maintain the availability of the valuable copyrighted works and to protect them from decaying is a dynamic incentive which may be considered relatively constant over time and little affected by discounting. Hence, extending the term of protection may be a significant incentive for copyright owners to maintain over time the availability and quality of the copyrighted works produced in the distant past.

Although copyright term extension may represent additional costs (payments for copyrights) for users, publishers, archivists, and the general public, it seems that on balance, considering the fair dealing provisions and other exceptions from copyright infringement, they themselves do benefit from a better maintained stock of available works.

\section{The economics of discounting and of post-creation changing of rules/regulations}

Opponents of term extension claim that the main economic benefit of copyright protection is to give an author an incentive to create new works and that the importance of this economic incentive depends upon the present discounted value of future expected compensation as perceived by the creator at the time of creation. They argue that although term extension for new works may provide some anticipated gains/compensation for an author, the additional compensation occurring many years in the future has a relatively small present value, hence a very small and even insignificant incentive for an economically minded author of a new work. ${ }^{22}$

It is true that discounting makes values far away in time quite low as seen from today's viewpoint, that is, in present value terms. However, we do not confiscate wealth after $\mathrm{N}$ years (say 50 years after the death of the entrepreneur who creates it) simply because the incentive of the entrepreneur to exert significant effort and wisdom leading to the creation of that wealth would not be significantly affected by what would happen such a long time in the future. A similar case could be built for serendipitous discoveries and creations.

\footnotetext{
${ }^{21}$ CMPA and CMRRA, Recommendations for Reform of the Copyright Act, R.S.C., 1985, c. C-42, Submission on Copyright Act Reform, June 2018.

${ }^{22}$ For example: Consider a royalty payment of $\$ 1$ per year. Over a life +30 term of copyright, the present value of that annual copyright payment with a $10 \%$ risk-adjusted discount rate (a reasonable rate given the systemic risk involved), amounts, at the time of the creator's death, to $\$ 9.43$; adding one additional year for a term of life +31 years raises the value to $\$ 9.48$. Adding 10 years, for a term of life +40 years, raises the value to $\$ 9.78(+3.7 \%)$. Adding 10 more years, for a term of life +50 years, raises the value to $\$ 9.91$ (an additional 1.4\%). Adding 20 more years, for a term of life+70 years, raises the value to $\$ 9.99$ (an additional $0.7 \%$ ). In each case, the evaluation is obtained at the time of the creator's death.
} 
In a 2005 paper, Liebowitz and Margolis ${ }^{23}$ pinpointed a number of serious imperfections in the discounting argument. ${ }^{24}$ They raise the possibility that small increases in payment need not have small impacts on the creation of additional works. For some creators, in some range of income and propensity to create, a small increase in present value of royalties could make an important difference in creative output, perhaps because they reach a point where they switch to full-time creating. And the converse is possible too: a small decrease in present value of royalties could make an important difference in creative output, perhaps because they reach a point where they switch to part-time creating activity or even quit. ${ }^{25}$

If this is the case, small increases in payments from copyright term extension might result in large increases in the number of creative works produced, which in turn might produce significant social benefits. Small changes in incentives may have huge impacts. This is a case of a significant elasticity at the interval of interest along the supply curve, that is, of the straw that breaks the camel's back.

Opponents of term extension claim also that term extension for existing works makes no significant contribution to an author's economic incentive to create, since in this case the additional compensation is granted after the relevant investment had already been made.

Clearly term extension cannot change the incentives of creators in existing works since those works were already fixed at the time of the extension. But, changes in rules and regulations happen all the time and businesses consider the risk of future changes in rules and regulations when making decisions regarding production, technology, and investments. Did creators anticipate the possibility of future changes in copyright term at the time of creating their works, given the history of changes in copyright terms over time? I would say most probably yes, implicitly if not explicitly. They could not know for sure if and when such copyright term and other relevant changes would occur but there is no reason to exclude such considerations.

\footnotetext{
${ }^{23}$ Stan Liebowitz and Stephen Margolis (2005), "Seventeen Famous Economists Weigh in on Copyright: The Role of Theory, Empirics, and Network Effects", Harvard Journal of Law \& Technology 18(2), 435-457. The article was published after the US Supreme Court had ruled in Eldred against the petitioners (and the seventeen economists' amicus curiae brief) by upholding the CTEA. See Appendix B. See also Scott Martin (2002), "The Mythology of the Public Domain: Exploring the Myths Behind Attacks on the Duration of Copyright Protection", 36 Loyola of Los Angeles Law Review, 253. http://digitalcommons.lmu.edu/llr/vol36/iss1/7

${ }^{24}$ In their own words, "A more complete view requires consideration of the responsiveness of creative efforts to marginal incentives and the function of ownership of intellectual property beyond the incentive to create. A more nuanced view requires attention to the limitations in the exclusionary aspect of copyright law. A more correct view requires an examination of empirical magnitudes that no one has fully undertaken."

${ }^{25}$ Liebowitz and Margolis also argue that copyright in creative works may internalize potentially important network externalities in the use (or misuse) of existing works and the creation of derivative works. Insofar as important network externalities exist in the use of works falling into the public domain, term extension would be welfare enhancing and hence justified. They suggest that the presence and importance of network effects on welfare must be assessed before deciding whether withdrawing copyright (letting the works fall into the public domain) or extending the copyright term on efficiency grounds.
} 
In the present case, numerous actions can be taken regarding existing works in reaction to a term extension, to the benefit of creators, creative businesses, and the general public. New possibilities for exploitation of existing works open up. Additional commercial value may be seized.

Evaluating investments, in particular investment in creations, in a complex undertaking. Numerous errors must be avoided, Simple and straightforward discounting is not the proper way to proceed. ${ }^{26}$ When a creative business invests in a portfolio of creators or works, it is likely that most of them will end up as money-losing adventures. The distribution of success is very asymmetric with many failures and few successes. Hence, the profitability of a creative business and its capacity to support the development and promotion of creators rely on the small number of highly successful ones that can only be identified ex-post. If termination and reversion end up cream skimming the distribution of works, it is clear that creators as a whole will be the main losers of those changes.

\section{The deadweight loss of pricing above marginal cost}

Economists refer to a loss of potential value as deadweight loss. A deadweight loss arises when pricing (royalty payments) is set above the marginal cost of use and the marginal value to the user of unused additional units is lower than the price but above the marginal cost. ${ }^{27}$

Opponents argue that term extension raises the present value of the additional deadweight loss by a small amount for new works but a much larger amount in the case of existing works. However, deadweight loss is part of an efficient second-best or revenue-constrained solution; in other words, it is an efficient solution under this constraint of properly compensating creators through copyright and royalties.

\section{A critical review of the reversion and termination rights recommendations}

\section{The risks involved and their impact on value}

A film or TV production consists of many components - scripts, costumes, sets, scores, set decorations, etc. - each of which is protected separately by copyright. Where the production is based on an existing book or other literary property, the underlying rights are also protected separately. The producer needs to license or acquire the right to use each of these components to complete the production. Where the author was the first owner of copyright in a component and either assigns or grants an exclusive licence to the producer, the copyright to that component in

\footnotetext{
${ }^{26}$ For a discussion of important and ubiquitous errors in investment evaluation, see Marcel Boyer, « Erreurs méthodologiques dans l'évaluation des projets d'investissement », Revue Française d'Économie XXXIII (2018/4), avril 2019, 49-80.

${ }^{27}$ Insofar as the pricing is set above the marginal cost of use during the term of copyright, it means that the marginal or last unit used generates a positive net social value.
} 
Canada will revert to the author's estate 25 years after his or her death, regardless of the parties' intentions to the contrary. The Copyright Act specifically precludes the parties from contracting around or out of reversion; any attempt by the author to do so is void. ${ }^{28}$

So, from the standpoint of a film or TV producer, there is a distinct risk that, even if it has acquired rights to copyrighted material by legitimate means, and even after it has invested additional resources in a film or TV production using that material, it will lose those rights in Canada automatically, 25 years after the author's death. At that point, its options are rather unattractive: attempt to reacquire the rights from the author's heirs or estate, if they can be located and are willing to negotiate; replace the reverted content with a non-infringing substitute, which is rarely feasible (and always expensive); risk infringing copyright by continuing to exploit the work despite the loss of rights; or forgo any further return on the original investment by ceasing exploitation altogether.

Of course, the problem is not limited to the film and TV industries. Record labels, music publishers, and creative businesses of all kinds determine how much to invest in the creation of new content according to the length of time available to exploit it and the revenue that they expect to earn during that time. Indeed, the revenue generated from the exploitation of existing content is the predominant source of working capital to finance the creation of new material. Simply put, the loss of reliable revenue that occurs when copyright reverts to the estate of a creator means less money available to sign new artists or pay advances to established ones for the exploitation of their proven hits.

Mr. Tarantino, Counsel at Dentons Canada, summed it up before the INDU Committee: "Given the uncertainty of their ownership and the fact that they will not be legally entitled to exploit rights in the work during the last twenty-five years of the copyright term, informed assignees and licensees will be inclined to discount the value they are prepared to pay up-front to an author for a work."

Reversion also leads to a deeply counterintuitive market dynamic: the closer a work is to reversion, the less valuable it is in the market. As Mr. Tarantino put it before INDU, "owners will be disinclined to invest resources towards the exploitation of a work which is nearing the reversionary threshold, because they will be uncertain whether an author's heirs will assert a reversionary claim." That means that a rational actor will be less likely to invest in the work of an elderly creator, since the exploitation window will be constrained artificially by the risk of reversion. It also leaves the creator's heirs unable to capitalize on the resurgence of public

\footnotetext{
${ }^{28}$ Unlike the U.S., Canada does not recognize the "work made for hire" doctrine, which deems the commissioning party to be the author and first copyright owner in many cases, including where the work was commissioned specifically for inclusion in an audiovisual work. The Canadian "work made in the course of employment" doctrine is much narrower and does nothing to avoid reversion in film or TV unless the author of a work happens to have been an employee of the production company - or, possibly, his or her own loan-out company - in which case the company, not the author, will be the first owner of copyright in the work and reversion will not apply.
} 
interest that often follows the death of a popular artist - precisely the opposite of what a postmortem copyright term is intended to achieve. By the time it is once again "safe" for creative businesses to invest in the work, its commercial value may be greatly diminished.

An even greater risk would apply if Canada were to introduce termination rights, whether instead of or in addition to reversion. Creative businesses would be faced with an even more imminent prospect of losing key underlying rights, and the risk would be increased by the publicity that would no doubt accompany the introduction of these new rights.

In purely economic terms, the significant uncertainty that exists regarding the future market value of copyrighted works and sound recordings, must be and is generally considered when a contract is signed between a creator and a creative business. The total present value (royalties) of a creator's creations, to be shared between the creator and other stakeholders, including creative businesses and their financial investors, is the expected development over time of the future market value (royalties) of those creations over the contract period actualized in today's dollars, as in any other business, at a proper risk-adjusted discount rate.

The calculus is simple: the higher the expected future value of the creations, the longer the contract period; the lower the risk in future royalties, the larger the present value to be shared.

There is no magical thinking here: the only way to increase the present value of copyright royalties is to increase the quantity and quality of creations, as perceived by the market (end consumers), to increase the length of the contract period over which the discounted value is calculated, and to reduce the risk of future royalties. Reducing the risk can be done, for instance, through a better diversification of royalty sources (a pooling of risks among creators under a given creative business) and a more predictable evolvement of the contract through better designed, more transparent, and higher intensity of incentives rules under which the contract is managed and may be terminated. As a matter of economic theory, those three factors boil down to a present value to be shared in the most effective and efficient way in the creator's interest, including both compensation upfront and over time as well as investment in proper management and marketing of the creator's creations.

A more cumbersome set of copyright rules, raising transaction costs, and a set of riskier termination or reversion rules would tend to depress the value of copyrighted works in the eyes of users, and hence the value to creative businesses, thus reducing the discounted present value of copyrighted works and the upfront compensation of creators. Increasing uncertainty in the exploitation of works, both on their own and in their embeddedness into adaptations or other derived works, would also tend to reduce the upfront compensation of creators. 


\section{The (reduced) availability of works}

Two particularly prevalent misconceptions about the effects of term extension, reversion rights, and termination rights are the so-called reduced availability of works and the lack of growth of the public domain. For further discussion of additional misconceptions, please see Appendix "C".

Opponents argue that term extension leads to a reduced availability of works, which would have fallen into the public domain absent the term extension. This argument seems to concern books rather than music. Music has never been more available worldwide and time wise. Copyright constrained availability in music is not a problem.

As for books, Heald $(2018)^{29}$ discusses the U.S. termination of rights: Under 17 U.S.C. $§ 203$, transfers of copyrights in works published after January 1, 1978, can be terminated 35 years after the transfer, either by the author or her heirs. ${ }^{30}$ Under 17 U.S.C. $§ 304$, transfers of copyrights of books published between January 1, 1950, and January 1, 1978, may be terminated 56 years after publication, or 75 years after publication if the opportunity at year 56 went unexploited. ${ }^{31} \mathrm{He}$ provides the following summary of his work:

Copyright keeps out-of-print books unavailable to the public, and commentators speculate that statutes transferring rights back to authors would provide incentives for the republication of books from unexploited back catalogs. This study compares the availability of books whose copyrights are eligible for statutory reversion under US law with books whose copyrights are still exercised by the original publisher. It finds that 17 USC $\S 203$, which permits reversion to authors in year 35 after publication, and 17 USC $\S 304$, which permits reversion 56 years after publication, significantly increase inprint status for important classes of books... Several reasons are offered as to why the $\S 203$ effect seems stronger. The estimated positive effect of reversion on the availability (in-print status) of titles in the full sample of 1909 books is $20-23 \%$.

Heald also discusses the rationale behind the reversion of rights. A first set of reasons offered by Heald revolves around the paternalistic protection of creators, as legislators are worried about creators who may have made bad deals with their publishers or about heirs who might not be adequately benefitting from their parents' or grandparents' labor.

\footnotetext{
${ }^{29}$ Paul Heald (2018), "Copyright reversion to authors (and the Rosetta effect): An empirical study of reappearing books", 66 J. Copyright Society of the U.S.A. 59. https://papers.ssrn.com/sol3/papers.cfm?abstract id=3084920 ${ }^{30} 1978+35=2013$.

$311950+56=2006$.
} 
We saw these reasons from proponents of modified reversionary rights and the introduction of termination rights. However, they are not particularly convincing as any future changes in copyright rules, including reversion or termination of rights, will be discounted to the present and lead to a smaller value of payments to be transferred upfront or over time to the authors and creators.

Of course, ex post when the future has become the present, some books and works will have maintained or acquired a value different from the one expected at the beginning. Creative businesses make deals with creators based on a distribution of future values of creations. Nothing in the Copyright Act prevents contracts from taking different forms, some being struck based on discounted expected future values (expected contracts) and others being struck on the basis of conditional future values (conditional contracts) as they become known over time. In the end, for the first type of contracts, some deals will have paid creators way more than the observed or realized value of their works and others will have paid much less. For the second type of contracts, some creators will end up in less favorable conditions than under the first set of contracts.

As in insurance markets, risk aversion of creators will explain their choice of contracts: the less risk averse choosing the conditional contracts and the more risk averse the expected contracts. There is no one size fits all here and the Copyright Act does not prevent contracts from taking different forms. It is better to leave the decision to those directly concerned, creators and the creative businesses that support them.

A second set of reasons offers a different view: after a certain period, creators may do a better job than creative businesses of making works available to the public or of creating new derivative works. Why? This second set of reasons is not convincing either, as the marginal costs involved in exploiting small market opportunities are much lower for large publishers, for example, than for authors and small publishers. Why would larger publishers leave easy money on the table?

Of course, that does not mean that "errors" are not or cannot be made. For a convincing analysis, however, one would need to evaluate decisions on books in-print as some of those may turn out to be failures. Larger publishers possibly keep in-print books that should have been dropped and keep out-of-print books that should have been reprinted, and the same is probably observed for smaller publishers.

In other words, Heald looks only at one tail of the distribution, that is, books that are out-of-print and are reprinted when they fall into the public domain. But to provide a balanced picture of publishers' decisions, it would have been necessary to consider those books in-print that should have been out-of-print based on their diminished popularity. It is quite likely that the two tails of the distribution are cancelling out. 
For these reasons, even beyond the inherent limitation of his analysis to books rather than to music, films, and so on, Heald's results are simply not convincing.

Heald offers the following final comment: "This study suggests, however, that shifting the ownership of a copyright from the initial transferee/publisher may, under the proper circumstances, result in the republication of out-of-print books (emphasis added) ...." It appears that this comment is mainly due to the Rosetta effect, as confirmed by Heald himself: "The 2002 decision in Random House v. Rosetta Books, which worked a one-time de facto reversion of eBook rights to authors, has an even greater effect on in-print status than the statutory schemes."

Rosetta may not bite in the future as publishers can be expected to negotiate renewed contracts with authors to redefine rights in all print and digital versions of books. On the other hand, the threat of reversion and the uncertainty it creates may, just like Rosetta, have a negative effect on availability, causing some books to go out of print.

As Heald mentions, "Other studies will have to be conducted to estimate the optimal timing for rights reversion, but the US experience provides some support for schemes that are easily understood by authors .... Given the wide variety of reversionary schemes around the world, the data necessary to craft an optimal regime may be just a few new studies away."

I should add that given the complexity of the copyright microcosm and ecosystem, and given in particular the information good character of literary and musical works, taking a pro-creator stand and willing to help creators financially and otherwise cannot be made concrete without a fine understanding of the roots of the problem (see The problem of creators' compensation: The size of the pie and the sharing of the pie in Appendix "A").

Taking the easy but ineffective step of intervening, through reversion and termination, in the contractual relationship between creators and their main partners, creative businesses as publishers and record labels, is not the solution. To the contrary, it is likely to generate more harm than good.

\section{The (lack of) growth of the public domain}

Another myth claims that term extension will simply leave Canadians with 20 additional years of no new works entering the public domain. While true as a matter of simple arithmetic, this is a short-term phenomenon. Because copyright term extension incentivizes creators to create more and better new works in addition to better maintaining and marketing existing works, the quantity and quality of copyrighted works that will fall in the public domain will eventually increase. Barker puts it very clearly: "Despite this myth, the exact opposite is true. Ultimately there will be more sound recordings created, and therefore more supply into the public domain, with a longer copyright term." 
Moreover, if the sole policy objective were to develop and promote the public domain, it would follow that Copyright Act should be amended to reduce significantly the term of copyright from life plus 50 to, say, life plus 25 . However, that clearly would not be in the best interests of creators or the general public for all the reasons provided above.

Finally, it is important to reaffirm that copyright term extension does not prevent the publication of works or their commercial exploitation under different forms. All it does is to favor the emergence of proper market-like mechanisms under which the creators of the works themselves, as essential input providers, are properly and competitively compensated, alongside the owners of public domain businesses, the investors in those businesses, and the suppliers of offices, technology, and other labour and materials necessary to commercially exploit the works. ${ }^{32}$

\section{The challenge of efficient registration reform}

In his analysis of the Eldred case, Rimmer (2003) recalls that Lawrence Lessig, the main lawyer in the case, put forward a fall-back position in 2001:33 "Patent holders have to pay a fee every few years to maintain their patents. The same principle could be applied to copyright... That way artists and others who want to use a work would continue to have an easy way to identify the current copyright owner. But if a copyright owner fails to pay the tax for three years in a row, then the work will enter the public domain." 34

Rimmer continues:

Although it may seem to be an elegant conceit, this law and economics model of indefinite, renewable protection would be diabolical in practice. There are dangers in turning copyright into a registration system. There would need to be a large register because originality is pitched at such a low level. Such a regime would need to be administered by a bureaucracy. This scheme would have invidious effects in terms of justice and equity. Artists and creators

\footnotetext{
${ }^{32}$ We often hear the fable that a dwarf on the shoulder of a giant sees farther than the giant to justify the use free of royalties of older works by current creators and other groups. John of Salisbury wrote in 1159: "Bernard of Chartres used to compare us to dwarfs perched on the shoulders of giants. He pointed out that we see more and farther than our predecessors, not because we have keener vision or greater height, but because we are lifted up and borne aloft on their gigantic stature." (The Metalogicon - A Twelfth-Century Defense of the Verbal and Logical Arts of the Trivium, 1159, trans. D.D. McGarry. Berkeley and Los Angeles: University of California Press. 1955)

${ }^{33}$ Lawrence Lessig (2001), The Future of Ideas. New York: Random House.

${ }^{34}$ The idea of a copyright term with repeated renewal (perpetual) with costly registration was discussed by Richard Posner ("The Law and Economics of Intellectual Property," Daedalus (Spring 2002), p. 5). He wrote: "The solution might be a system of indefinitely renewable copyrights. The initial grant might be for twenty-five years, renewable thereafter every five years. A stiff fee would assure that most works returned to the public domain. But those works requiring continuing investment or careful management to avoid consumer exhaustion would continue to be owned property." William Landes and Richard Posner ("Indefinitely Renewable Copyright," Working Paper, Olin Center for Law and Economics, the University of Chicago 2002. http://www.law.uchicago.edu/Lawecon/WkngPprs_151175/154.wml-rap.copyright.new.pdf) engage in an empirical economic analysis and conclude that "a system of indefinite copyright renewals need not starve the public domain."
} 
would risk being disenfranchised if they could not afford registration fees.

By contrast, the main media conglomerates would be able to easily pay

renewal fees to secure perpetual protection. Moreover, the trend in

international copyright law is towards the removal of formalities in copyright

law. Most notably, the United States has been removing formal requirements

for copyright subsistence, in line with the Berne Convention. Most

importantly, the proposal concedes too much in its attempt to salvage public domain. [emphasis added]

Besides the arguments put forth by Rimmer, the strongest economic argument against registration is that it significantly raises transaction costs and introduces significant uncertainty in the system. In the face of that criticism, Lessig and others have sometimes proposed only a nominal renewal fee. Still, from an economic perspective, it appears that a registration-based system - especially one that requires mandatory renewal by heirs or successors who, unlike the creators who preceded them, may not be steeped in the creative ecosystem and therefore may be unaware of their legal obligations - would be little more than a trap for the unwary. Unless some reasonable arguments, studies and measures can be provided to show that the actual system of copyright ownership is seriously broken, even despite the existence of well-functioning collective societies whose entire raison d'etre is to facilitate efficient licensing and payment to rights holders, it is better not to fix it.

The main reason advocated by INDU for such a cumbersome registration system is to mitigate the negative effects of term extension. It looks very much like resorting to a bazooka to kill a fly.

\section{Conclusion}

Term extension is fully compatible with economic efficiency principles regarding the allocation of resources to the production and dissemination of information goods as well as incentives for creativity. Copyright term extension will favour the increase in the supply of new creation goods.

The most important and pressing copyright agenda today centers on two challenging tasks: the discovery of the competitive market value (or at least the fair and equitable value) of copyrighted works and the identification of sources of compensation to cover that value. If the Committees wanted to increase compensation to creators, they should have proposed amendments to the Copyright Act that would raise the revenues of all rightsholders and their partners towards their competitive levels. Instead, they focused their attention on the sharing of the pie, proposing to play Robin Hood by taking from creative businesses with the apparent intention of giving more to creators. In practice, however, the measures proposed are likely to reduce not only compensation to creators but also investments by creative businesses in other works. In order to increase compensation to creators, the urgent and more important task is to increase significantly the size of the pie itself so that it reaches its competitive market value level. 
Maintaining the reversion right and introducing a new termination right would affect the sharing of royalties between different stakeholders and partners in creative activities and products. Similarly, the introduction of a mandatory registration requirement would introduce significant uncertainty into the management and marketing of creative activities. As a result, their most probable effect would be to reduce the size of the royalty pie (the future expected royalty payments discounted at a risk-adjusted discount rate), not to increase compensation to creators or promote the public interest in creation and dissemination. In the end, these amendments would likely generate more harm than good to the creators they were intended to support.

\section{APPENDIX A. The economics of copyright: a difficult economic problem}

It is extremely difficult to assess the so-called economic impact of different changes in copyright laws on different relevant groups of stakeholders given the relative scarcity of reliable consistent data. ${ }^{35}$ It is therefore important and somewhat urgent that the different stakeholders embark on a significant endeavour of building a concerted and integrated database on all aspects of intellectual property: people, contracts, payment levels over time, distribution, sharing, related production and distribution industries, etc. It is necessary to start with the current state of the available data and then move on to the design of an integrated database using all relevant reporting methodologies. The effort is significant, will require important resources, and must rely on the collaborative involvement of many different people (statisticians, economists, experimentalists, pooling/survey specialists, psychologists, and lawyers) aiming collectively at better understanding the intricate determinants not only of creating but also of pirating and (illegal) copying, and at better measuring those determinants as well as the end results themselves.

\footnotetext{
${ }^{35}$ For one particularly illuminating glimpse at the complexity of these issues, see Julia Reda (Committee on Legal Affairs of the European Parliament), Draft Report on the implementation of Directive 2001/29/EC of the European Parliament and of the Council of 22 May 2001 on the harmonisation of certain aspects of copyright and related rights in the information society (January 2015) on the history of copyright reform in the European Community starting with Commission of the European Communities (2003 - https://eur-lex.europa.eu/legalcontent/EN/TXT/?uri=celex\%3A32001L0029) and European Union (2001 - https://eur-lex.europa.eu/legalcontent/en/ALL/?uri=CELEX\%3A32003L0098). See also Hugenholtz (2000 - "Copyright vs, freedom of scientific communication". Learned Publishing (2000)13, 77-81. https://onlinelibrary.wiley.com/doi/epdf/10.1087/09531510050145380). For a discussion of the different reports on the harmonisation of copyright in Europe including, besides the Reda Report, the reports by Caroline de Cock (2015 - The Copyright Manifesto: How the European Union should Support Innovation and Creativity through Copyright Reform. Copyright4Creativity. http://copyright4creativity.eu/wpcontent/ uploads/2015/01/C4C-Copyright-Manifesto-20150119.pdf), Richard Malka (2015 - The End of Copyright - Taking for free is Stealing. Syndicat National du Livre (SNE, IFRRO). http://www.sne.fr/wpcontent/uploads/2015/09/R.Malka_TakingForFreeIsStealing.pdf), and The US Copyright Office (2015 - Copyright and the Music Marketplace: A Report of the Register of Copyrights.

https://www.copyright.gov/policy/musiclicensingstudy/copyright-and-the-musicmarketplace.pdf), see Marcel Boyer, "The Competitive Market Value of Copyright In Music: A Digital Gordian Knot, CIRANO 2017s-14 https://cirano.qc.ca/files/publications/2017s-14.pdf.
} 
Rather than continuing to "beat up a dead horse" or "drawing lines in the sand," it seems more useful to look for another kind of data, namely what we could call data on processes, that is, the processes by which, on the one hand, creators and inventors are encouraged to use efficiently their capacities and, on the other hand, the public is adequately served in such a way that, conditional on the level of incentives being adequate to encourage a proper level of creativity, the creations so produced are distributed as widely as possible and as efficiently as possible. Hence, rather than trying in vain to 'quantify the impact' of different changes in copyright protection on different groups of stakeholders, including the general public, it appears more useful at this time to ascertain if the changes in question allow, or at least favour, a betterment of the processes that govern the production and dissemination of copyrighted works. If the answer were yes, then the changes would be deemed to be warranted. If not, then the changes should be reconsidered or simply dropped.

The distribution of creative abilities over individuals is of course very difficult if not impossible to characterize. It seems that our efforts would be better spent if instead of trying to characterize this distribution, we were to assume and use as a postulate that the distribution of creative abilities over individuals is uniform over population groups (countries) and periods of time. It is how these individuals are induced to become creators and develop their abilities, whether innate or learned, that differs or may differ between groups and countries as well as between time periods. $^{36}$

Creators exist everywhere. Sometimes, creators' talents and skills (like entrepreneurs') are used for the betterment of society at large and sometimes they are not. Even when creators' talents and skills are systematically used for the betterment of society at large, the level at which they are so used may differ based on the system of incentives at work. Those incentives must aim at properly encouraging the creators and entrepreneurs without giving them undue control of, or market power over, the "information and cultural goods" that they may have created. Hence, the notion of "proper encouragement" must rest on a proper balance between the interests of society in fostering high quality creativity in the information and cultural industrial sector, sometimes referred to as the interests of the creators, and the interests of society in fostering the consumption and use of the goods and services produced by the information and cultural industrial sector, sometimes referred to as the interests of the public at large.

It is important to stress that in both cases, the interests of society represent the reference point. ${ }^{37}$ Hence, we take a slightly different point of view from the more usual one, which is presented in terms of balancing private interests and public ones. ${ }^{38}$ To achieve such a balance is both a

\footnotetext{
${ }^{36}$ Baumol (1993) argues for such an approach for understanding the emergence of entrepreneurs in society.

${ }^{37}$ Hence, we are not considering here as relevant the view, as developed in Murray (2004), that copyright laws affirmation and enforcement are basically promoted by "the interests of American and international capital" against the interests of the public at large. On the contrary, we develop here a strict social efficiency analysis.

${ }^{38}$ As stated by Musick (2004, page vii) for instance: “... copyright law has sought to balance private incentives to engage in creative activity with the social benefits that arise from the widespread use of creative works."
} 
condition of social efficiency and a moral obligation to respect the reputation of the creators, the integrity of their creations, as well as the rights and needs of the public. ${ }^{39}$

\section{The socio-economic efficiency conditions.}

How to determine if the levels of production and/or consumption of a good or service are adequate? Although the goods under consideration in copyright law correspond in general to non-rival goods, that is goods which, once created or produced, can be consumed in total by everyone without additional production costs (but possibly not without additional distribution costs), it may be useful to consider under what conditions the production and/or consumption of ordinary rival goods can be considered to be adequate.

For illustration purposes, let us consider the case of tomatoes, a clear case of rival good given that once a tomato has been consumed by someone, the same tomato cannot be consumed by someone else: consumption completely destroys the good.

\section{The case of tomatoes}

One way to proceed is first to evaluate the technologies used in growing and distributing tomatoes to obtain some estimate of the cost function (and the marginal or incremental cost function), and second to evaluate the consumers' willingness to pay (and their marginal willingness to pay) for tomatoes. The cost functions will depend on all production activities being undertaken in the economy insofar as the prices of all factors of production and distribution in the tomato industry are influenced by, and must compete with, all the alternative uses to which these factors can be put to. Similarly, the consumers' willingness to pay will depend on all the goods and services insofar as those consumers will choose among the different goods and services on the basis of their own preferences, the characteristics of the goods and services, and the relative prices they are facing. In that sense, the characterization of the amount of tomatoes as being adequate or not requires the solution of a general equilibrium problem, where in a sense everything depends on everything.

To maximize the total value or surplus generated by the exchange of tomatoes between growers and consumers, one must find the level of exchange where two conditions are met: first, the marginal cost must be equal to the marginal willingness to pay and second, the total cost must be lower than the total willingness to pay. This is clearly a titanic task, a quasi-impossible one.

An alternate way to proceed is to analyse how transactions are made on the market of tomatoes between growers and consumers. If tomatoes, as well as all other goods, are exchanged freely

\footnotetext{
${ }^{39}$ As early as 1984, the issue of the proper balance between those different interests and how more extensive copyright protection may affect that balance were discussed by Novos and Waldman (1984) among others. See also Hirshleifer and Riley (1979), Arrow (1962), Ploman and Hamilton (1980), and more recently Silva and Ramello (2000) and Musick (2004).
} 
between willing buyers and willing sellers and if markets are reasonably transparent and competitive, one can infer that the level of transactions is most likely efficient in the sense that all possible valuable trades are executed, all gains from trade are fully realized, and total surplus is maximized.

\section{Contrasting the case of information goods}

This analysis applies also to creative activity, copyrighted works and more generally information goods. Except for one very important aspect: the marginal cost of reproducing an information good (a musical work, a sculpture, a computer program, etc.), which is already created and therefore available for consumption, is zero or very close to zero. However, the marginal cost of creating such information goods remains significantly above zero. Which marginal cost to use?

The cost of creation is quite similar to an investment cost or a fixed cost. Information goods have a relatively high fixed cost and a relatively low variable (reproduction) cost, the latter being in some cases very close to zero. The first-best social efficiency rule calls in such a case for selling the good at its marginal cost and covering the deficit through a government subsidy financed by non-distortionary taxation, insofar as the total willingness to pay by all present and future consumers is larger than the cost of creating the good; otherwise it would be better not to create the good. In so doing, creation is properly financed, creators are properly remunerated, and their works can be made available to all at the low reproduction cost. In the limit, all creators should be publicly funded, that is, should in some way be social, public, or government employees!

This is likely to be less efficient than suggested because of the social cost of public funds (from distortionary taxation $)^{40}$ and because of the possibilities for collusion and corruption, leading to too many or too few creators and too much or too little creative activity. Some creators, hopefully the less productive quality-wise, should rather be induced to enter the ordinary labour force and produce other goods. At the same time, the remaining creators should be induced to avoid overproduction of works or the production of works of low or insufficient quality. Again, determining the proper number of creators and their proper level of production, in quantity and quality, is a resource allocation problem requiring the determination of a general equilibrium as the solution to a general resource allocation problem, clearly a titanic and impossible task.

It may then be useful to relax the unrealistic if not impossible first-best efficiency objective in favour of a more reasonable second-best one. Indeed, the relevant social efficiency conditions are not the full information first-best conditions, which economists are accustomed to work with and that are often referred to in discussions, but rather the private-market-like budget constrained efficiency conditions. ${ }^{41}$ Imposing a self-financing constraint (alternatively, not fully financing

\footnotetext{
${ }^{40}$ Jones et alii (1990) estimate that this cost is of the order of $30 \%$ of the funds collected through taxation in developed countries: each dollar collected generates $0.30 \$$ in deadweight loss to the economy.

${ }^{41}$ More generally and more realistically, one would like to aim to meet the imperfect and incomplete information (under moral hazard and adverse selection), budget constrained, and institutionally restricted efficiency conditions.
} 
the creators from public money, or not employing them as public employees) on the creation sector is a significant institutional constraint which prevents the full information first-best conditions to be met.

One way to go is to consider the Ramsey-Boiteux pricing rule: allowing prices of copyrighted material, goods and services, to differ from marginal reproduction costs in order to satisfy a budget balance condition in the 'creation sector' of the economy. This budget balance condition requires that the price premium over marginal reproduction cost be sufficient to cover the (fixed) cost of creating the works in the first place. The second-best efficiency objective would be met if the prices of copyrighted works were set above their marginal reproduction cost (zero) in such a way that the resulting consumption levels of those copyrighted works would come as close as possible to the full information first-best ones (obtained under zero prices).

To achieve such a task, the Ramsey-Boiteux pricing rule requires that the margin between price and marginal cost as a percentage of the price be inversely proportional to the price elasticity of demand for the different copyrighted works. Hence, if the demand for some copyrighted work is relatively price inelastic, then the price premium charged for its use or consumption should be relatively high compared with those of other copyrighted works whose demand is rather elastic at relevant prices.

The relevant and difficult question is then: Is that (i.e., the Ramsey-Boiteux pricing rule) what the pricing of copyrighted works is likely to achieve in well-functioning markets for copyrights, at least from a global industry-wide viewpoint or in ex-ante expected terms, once the markets for copyrighted works become effective, that is, once copyrights are clearly defined, affirmed and enforced? At first glance, the answer to that question is yes. It is potentially and most likely one of the most important theoretical justifications of the recent efforts to reaffirm and enforce copyrights, in particular the recent WCT treaty and WPPT treaty.

\section{The Copyright balancing act: static vs. dynamic efficiency under institutional constraints}

How to achieve a proper balance between the different interests of society, that is, the interests of creators and the interests of the public at large, between sellers and buyers, now and in the future? The fundamental dilemma one must address as far as efficiency of copyright rules is concerned is the balance between static efficiency and dynamic efficiency under institutional constraints.

Static efficiency calls for the maximization of the use of copyrighted material whose reproduction can be done at zero marginal cost. Dynamic efficiency calls for ensuring the optimal production of new works, that is, the production level that equalizes the respective marginal cost of creating new works to the respective marginal social value. More precisely, a

See Boyer and Laffont (1997), Boyer and Laffont (1999), and Boyer and Porrini (2004) for discussions of those issues in other contexts. 
second-best optimum will be achieved in the production of works if and only if the creator can obtain, capture or appropriate the budget constrained marginal social value (the 'relevant social price') of his/her work. Comparing this (expected) marginal value or benefit to his/her marginal cost of creating the additional work, a rational creator will be expected to produce the proper quantity and quality of created work, thereby contributing to a socially efficient allocation of resources.

\section{Creators' compensation: The size of the pie and the sharing of the pie.}

There is currently an important debate among both academics and professional practitioners on the proper definition, coverage and characterization of intellectual property rights of all kinds, including copyrights and patents. ${ }^{42}$

At the center of this debate one finds arguments on the costs and benefits of protecting and enforcing intellectual property rights. The balance of costs and benefits is seen differently by different actors. Some see the costs of such intellectual property protection, in terms of a lower dissemination of creations and innovations and therefore a loss of socio-economic value due to impediments to further creations and innovations, as larger than benefits. Others see those benefits, in terms of an adequate intellectual property protection allowing proper compensation of creators and innovators thereby inducing them to increase their valuable but risky investments in further creations and innovations, as overshadowing costs.

Clearly, intellectual property rights should not be an undue impediment to further creations and innovations and therefore, should be properly defined and restricted in time and scope. As clearly, creations and innovations do not fall from heaven but are the results of significant incentives for creators and innovators to engage in proper efforts and risk-taking.

Pricing copyrighted works so that creators are competitively compensated has always been a difficult task given the "information good" character of such works: once produced or fixed, their use or consumption do not destroy such assets, which remain available for consumption now and in the future. In that regard, copyrighted works are different from usual public goods like national defense or security which must be produced in each and every period.

The balancing act here is to provide proper incentives for creators and innovators while at the same time fostering the dissemination of creations and innovations: proper incentives and proper dissemination rest fundamentally on the competitive market evaluations of value, costs and benefits.

We need a renewed, rigorous, and evidence-based research programme in the three essential facets of the compensation of creators and creative businesses: the size of the pie, the

${ }^{42}$ This section is inspired by my INDU brief of November 2018.

https://www.ourcommons.ca/Content/Committee/421/INDU/Brief/BR10249253/br-external/BoyerMarcel-e.pdf 
contributors or payers into the pie, the sharing of the pie among rightsholders, individuals, organisations, and institutions.

Market and market-like institutions for transactions on intellectual property rights, including fair dealing exceptions, compulsory licensing, and administrative boards and tribunals (such as the Copyright Board) with their role and mission as social welfare maximizers or market surrogates, can play a major role in achieving this programme.

The effects of extending the term of copyrights from life +50 to life +70 years or introducing a termination right (or modifying the reversion of rights) at some time can only be marginal on the discounted present expected (ex ante) value of works and sound recordings. That is not to say that for some works, value is indeed maintained and high or even rises ex post.

Those effects can only be of an order of magnitude smaller than bringing into the discourse rational, rigorous, and economics-based determinants of compensation based on the competitive market value of works, books and sound recordings.

By focussing on the extension of the term of copyrights and on the introduction of a termination right, there is a real danger of losing the forest for the trees!

\section{The challenges of reining in the elephants in the room}

The main questions to tackle regarding the size of the copyright royalty pie and its financing are the following:

- How to determine the "estimated/observed" competitive market value of copyrighted works? For example, what is the competitive market value of copyrighted musical works and sound recordings (performances) in Hertzian radio, Satellite radio, Online streaming services (Spotify and others), DPA services, and so on?

- Once this competitive value is determined or assessed, who should pay or contribute to paying it: end consumers, users (intermediaries), holding companies, governments?

- Who, besides creators (authors, composers, performers, and makers) and other rightsholders (publishers, record labels, distributors, and others), should pay for public policies towards exceptions (fair dealing, education, and others) and for public policies towards private copying?

- How to determine or redesign the sharing of the (renewed and expanded) pie between creators (authors, composers, performers, and makers) on the one hand and creative businesses such as music publishers and record labels on the other, that is, how to bring 
into the discourse rational, rigorous, and economics-based analysis of the determinant factors of the sharing of the pie?

Creators and creative businesses (collectives, publishers, distributors, record labels, etc.) are currently involved in a joint endeavour to maximize the value of creations. It is important not to create an artificial conflict between the two. The game being played is and must be framed as a cooperative bargaining game.

The recorded music and publishing industries (understood as the different ways of making information available to the general public, hence books as well as news/information reporting) are particularly important in the digital economy. They are in a sense leading the digital transition and fueling the Internet.

First, recorded music and publishing are activities prone to digitization. Second, new technologies used to sell and distribute music and publications on the Internet (webcasting and ondemand streaming, e-books, e-journals) raise the possibility of valuable large-scale dissemination and customization at relatively low marginal costs. Third, those technologies open music and publishing markets to increased intensity of competition due to the lower costs of entry of creators (authors, composers, performers, writers) of all time periods on a world-wide scale.

The digital revolution comes at a time when the value of copyrighted works appears to be both significantly underestimated and continuously eroded by new copyright exceptions. Digital technologies reduce to "zero" the cost of reproducing and disseminating copyrighted works such as music and books, making possible a maximal dissemination of works and thereby challenging the delicate balance between the respective rights of creators and users.

\section{The Gordian knot untied}

The determination of the competitive market value of copyrighted works is the most pressing, acute, and major challenge confronting us. The good news is that the Gordian knot of balancing on the one hand creators/rightsholders' rights to a fair and equitable hence competitive compensation and on the other hand the users' right to the benefits of digitization can be untied.

Let me concentrate hereinafter on copyright in musical works.

The competitive market value(s) of copyrights in music and the implementation of such value can and must be properly grounded in the economics of efficient allocation of resources, efficient negotiation/mediation, and cooperative game theory.

Rightsholders are significantly shortchanged by both the current Copyright Act provisions and the way they are implemented. The under-compensation of creators, as compared to the 
competitive market compensation benchmark, is a significant impediment to a more efficient and vibrant economy. ${ }^{43}$

This under-compensation totals today several hundred million dollars per year in Canada. In commercial radio alone, it reaches more than $\$ 300$ million per year. Such a level of under compensation dwarfs any super optimistic gains from copyright term extension or copyright termination/reversion.

I further argue that, for economic efficiency reasons, this gap should not be filled by primary users alone (such as radio station owners and operators) but by a broader set of beneficiaries, including equipment manufacturers, content and service providers, and other stakeholders, as well as the general public and governments.

\section{The stigmatisation of creators}

Public policies towards the development of a digital economy and the maximal dissemination of copyrighted works through copyright exceptions, including fair dealing, must avoid stigmatizing creators, implicitly if not explicitly, as the squeaky wheel of the cart. ${ }^{44}$

One well-known Canadian example will illustrate this stigmatization.

In October 2012, the Canadian Government issued a regulation aimed to exclude microSD cards from the definition of "audio recording medium" (used in smartphones, tablets, hard disks, etc.) and therefore prevent the Copyright Board from setting a levy on such cards to compensate rightsholders for the private copying of music on those music recording media and devices. The Government's sole argument: "Such a levy would increase the costs to manufacturers and importers of these cards, resulting in these costs indirectly being passed on to retailers and consumers ... thereby negatively impacting e-commerce businesses and Canada's participation in the digital economy."

Whenever I mention this regulation in my public conferences in the US, Canada and Europe, the attendees start laughing. What is less funny is that this regulation costs creators/rightsholders more than $\$ 40$ million per year, that is a discounted present value of some $\$ 800$ million at 5\% discount rate. Suffice it to mention that private copying levies aimed at protecting creators' rights

\footnotetext{
${ }^{43}$ See M. Boyer, "The Three-Legged Stool of Music Value: Hertzian Radio, SiriusXM, Spotify", pp. 13-40 in Ysolde Gendreau (ed.), Copyright in Action: International Perspectives on Remedies / Le droit d'auteur en action: perspectives internationales sur les recours / El Derecho de Autor en Acción: Perspectivas Internationales sobre los Medios de Protección, Proceedings of the 2018 World Congress of ALAI (Alliance littéraire et artistique internationale), Éditions Thémis, Montréal 2019, 490 pages. A longer more developed version appeared as "The Three-Legged Stool of Music Value: Hertzian Radio, SiriusXM, Spotify (The Working Paper Version v2)”, CIRANO 2018s-32 https://cirano.qc.ca/files/publications/2018s-32.pdf

${ }^{44}$ See M. Boyer, "The Economics of Private Copying", Toulouse School of Economics and Institute of Advanced Study in Toulouse policy paper 2017-08 (https://www.tse-

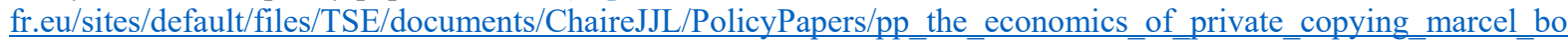
yer 31 august 2017.pdf)
} 
generate over $\$ 300$ million per year in France and in Germany compared to $\$ 3$ million in Canada. Those countries do not seem to fear that such levies are "negatively impacting ecommerce businesses and their participation in the digital economy", quite the contrary.

\section{The fair dealing provisions}

It may be useful here to discuss briefly the fair dealing exception that many contributors such as Landes and Posner (1989), ${ }^{45}$ Justice Ginsburg in Eldred, ${ }^{46}$ and Liebowitz and Margolis $(2005)^{47}$ rightly mention as one of the elements that reduce the power of rightsholders and therefore favour a larger dissemination and use of copyrighted works.

The Copyright Act includes several exceptions to the exclusive right of copyright holders, including the provisions concerning "fair dealing" in sections 29, 29.1 and 29.2. Those sections state that fair dealing in respect of a work for the purposes of private study, research, criticism or review, or news reporting, among other purposes, does not constitute a violation of copyright. Similar exceptions appear in most if not all national copyright laws throughout the developed world. Hence, although the current paper is rooted in the Canadian context, its messages and conclusions are relevant to the current worldwide debate on copyright extent and protection.

My 2012 article $^{48}$ addresses the following questions: What is the economic basis for the fair dealing exception in the Copyright Act? To what extent does the absence of efficient markets, which would allow creators and users to effect a monetary exchange in copyright matters, justify an expansive interpretation of fair dealing? What explains this absence of efficient markets for copyright works and what impact does the absence of such markets have on the creation and dissemination of literary and artistic works? What are the possible mechanisms for creating markets when markets could contribute to gains in productivity, efficiency, and creation thanks to lower transaction costs and reduced social costs due to the lack of such markets? To what extent should the fair dealing exception depend upon proof that its use has not had an unfavourable effect on the market for the works in question? The article is about the economics of fair dealing and as such it differs from more law-oriented ones.

To properly understand the source of the problems posed by the limits and exceptions that might be usefully introduced to copyright, particularly with respect to the concept of "fair dealing" in literary and artistic works [hereinafter referred to as "works"] and the market mechanisms that are likely to increase the economic efficiency of copyright, one must understand the conditions

\footnotetext{
${ }^{45}$ William M. Landes \& Richard A. Posner, An Economic Analysis of Copyright Law, 18 J. LEGAL STUD. 325 , 347-61 (1989)

${ }^{46}$ See Appendix B.

${ }^{47}$ Stan Liebowitz and Stephen Margolis (2005), "Seventeen Famous Economists Weigh in on Copyright: The Role of Theory, Empirics, and Network Effects”, Harvard Journal of Law \& Technology 18(2), 435-457.

${ }^{48}$ Marcel Boyer (2012), "The Economics of Fair Use/Dealing: Copyright Protection in a Fair and Efficient Way", Review of Economic Research on Copyright Issues 9(1), 2012, 3-46. http://papers.ssrn.com/sol3/papers.cfm?abstract id=2101080\#\#
} 
for efficiency (efficient allocation of human and physical resources, efforts, and talents to production and distribution) that are specific to such works. I will develop the analysis in the next section.

The Supreme Court of Canada (hereinafter referred to as "SCC") decision in the landmark case CCH Canadian Ltd. v Law Society of Upper Canada (hereinafter referred to as "CCH") is a famous Canadian case on fair dealing in which the Court emphasized that fair dealing is a users' right, thereby putting copyright users and owners on a kind of parity. In so doing, the SCC is relatively generous to fair dealing.

My article presents an economic analysis of the possible rationale for a relatively liberal interpretation of the fair dealing exception and considers the conditions that would allow efficient markets or market-like mechanisms to emerge. This leads me to comment on the appropriateness of considering those conditions among the so-called effects of fair dealing on the market for works, and hence on the value of works. I discuss market-like alternative institutions, particularly the role that an organization like Access Copyright in Canada and similar copyright collective organizations elsewhere may be able to play in increasing economic efficiency in the production and dissemination of protected works.

The analysis is developed in a law and economic framework and leads to the following conclusions.

First, there are purely economic reasons for the fair dealing exception to the exclusive rights of creators over their works.

Second, it is in the interest of a socially efficient static and dynamic allocation of resources to the production and dissemination of works in a manner consistent with the SCC decision in $\mathrm{CCH}$ that this fair dealing exception should be an integral part of the rights of users and ought not to be unduly thwarted. This is particularly the case when research and private study are the purposes of the use. In so doing, we must avoid unintended harm to copyright and foster the emergence of efficient means of exchange (market-based institutions) between users and creators. It is within this analytical framework that we must consider not only alternatives to the use of works but also alternatives to the exercise of the fair dealing exception itself.

Third, there are economic reasons for the absence of efficient exchange mechanisms (efficient markets) in copyright, particularly with respect to the right to reproduce works. This absence of efficient market mechanisms may have socially undesirable consequences on the production and distribution of original works, hence the importance of properly understanding the underlying reasons in order to be able to devote resources to solve the problems that may arise as a result.

Fourth, the identification and measurement of the effects of fair dealing on the work, the markets for the works, and hence their value are certainly factors that are relevant in establishing a 
reasonable framework for this copyright exception. The way in which those effects are measured must, if the expected results are to be achieved, be based on a broadened definition of the concept of a "market" and hence a broadened definition of the concept of "value." A market, from the standpoint of economic theory and analysis, includes not only the units transacted between sellers and buyers, but also potential buyers (those who would buy or buy more at a lower price) and potential sellers (those who would sell or sell more at a higher price), as well as future buyers and sellers. It includes also information providers who assess, analyze, or confirm the quality of goods and services, trend analysts and journalists who make sure that accurate news is available, suppliers of ancillary services within a market or related to a market. Finally, it includes the institutions that organize and facilitate transactions and process the associated financial transactions ensuring the necessary market liquidity, etc.

Fifth, preference should be given to policies that aim to create efficient, simple and low-cost market or market-like mechanisms that foster the production and distribution hence reproduction of quality original works, with due regard to the rights of authors-creators and users. I describe a market-like based mechanism which would not only favor a maximal dissemination of works but also avoid unnecessary recourse to the fair dealing exception.

My main contribution is to argue for a proper interpretation of what the SCC may (or must) have meant in $\mathrm{CCH}$ if the objectives pursued are to be met. Two elements of the decision are scrutinized and analyzed: the role of alternatives to the dealing in the work and the effect of the dealing on the work. The SCC stated in particular that existence of "alternatives" such as "noncopyrighted equivalent" works or "alternatives to the custom photocopy services" needs to be considered when deciding whether to allow a defense of fair dealing. When such alternatives exist, the dealing is likely unfair. However, the existence of a license is not considered by the SCC as a proper alternative to judge if the dealing is fair or not. I argue that "alternatives" shouldn't be seen only as "alternatives to dealing in the work." In addition, the inquiry should also consider the examination of alternatives to fair dealing in the work. The difference is important and crucial. For example, the existence of an efficient and inexpensive mechanism that could allow users to acquire copyrights without relying on the fair dealing exception should be considered as an alternative not to the use of the work itself but to the reliance on the fair dealing exception.

Regarding the effect of the dealing on the market for the works, I argue first that the preferred copyright policy should be to create properly designed efficient market-like mechanisms and institutions to favor copyright transactions, such as blanket licenses priced through copyright boards acting as surrogate for markets, and second that the first step in allowing a constrained optimum in production and dissemination of original works to emerge is to prevent its collapse. This collapse could result, under a more liberal interpretation of the fair dealing exception than is desirable, from the withdrawal of the object for which such blanket licenses are or could be issued. Hence, it is important to consider among the effects of the dealing on the works the 
possibility that a liberal interpretation of the exception might lead to the destruction in whole or in part of the emerging market-like mechanisms and institutions.

\section{APPENDIX B. Eldred (Us Supreme Court): Comments on Justices Ginsburg and Breyer}

\section{Justice Ginsburg}

As Justice Ginsburg puts it in Eldred for the majority: 49 "By establishing a marketable right to the use of one's expression, copyright supplies the economic incentive to create and disseminate ideas... The fair use defense allows the public to use not only facts and ideas contained in a copyrighted work, but also expression itself in certain circumstances... Members of Congress expressed the view that, as a result of increases in human longevity and in parents' average age when their children are born, the pre-CTEA term did not adequately secure the right to profit from licensing one's work during one's lifetime and to take pride and comfort in knowing that one's children and perhaps their children might also benefit from one's posthumous popularity... Congress passed the CTEA in light of demographic, economic, and technological changes, and rationally credited projections that longer terms would encourage copyright holders to invest in the restoration and public distribution of their works."

My comments as an economist on Justice Ginsburg's statement above about one's heirs is that clearly the role and importance of heirs is not to be neglected. The desire to leave one's children and grandchildren the possibility to benefit from of one's posthumous popularity if nay runs against and transcends discounting the future.

Say I buy at 40 an asset worth $\$ 1$ million (say a life insurance policy) that I intend to leave to my children and grandchildren after my death, possibly $\mathrm{N}$ years after my death. My life expectancy is say 85 . So the present value of my legacy 45 years from now at a $5 \%$ discount rate is about $\$ 110,000$. If my legacy falls into the hands of my heirs only 25 years after my death, that is 70 years from now, the financial present value is about $\$ 33,000$. Would I say never mind, I am not going to bother? Of course not.

But that is what the opponents to term extension seem to propose: creators should not worry today about leaving their heirs the value of their posthumous popularity if any. That may be what their financial advisor suggests but certainly not what their economic advisor would suggest.

Regarding the other two arguments in Justice Ginsburg's quote above, namely that copyright creates economic incentives for creation and dissemination of ideas as only expressions of ideas are protected, not ideas themselves, and that copyright allows the public to freely use

${ }^{49}$ Eldred, supra note 17 at 219. 
expressions also in some circumstances through the fair use defense, they are favoring the fair and equitable balance between users' rights and creators' rights.

The willingness of human beings, whether creators or not, to leave tangible assets to their heirs transcend the mathematics of discounting, in particular for the first and second generations of descendants. This behavior is a very important social and even evolutionary phenomenon.

\section{Justice Breyer}

Justice Breyer, ${ }^{50}$ in dissent, encapsulates the so-called cultural costs of the copyright term extension: "This statute, like virtually every copyright statute, imposes upon the public certain expression-related costs in the form of (1) royalties that may be higher than necessary to evoke creation of the relevant work, and (2) a requirement that one seeking to reproduce a copyrighted work must obtain the copyright holder's permission. The first of these costs translates into higher prices that will potentially restrict a work's dissemination. The second means search costs that themselves may prevent reproduction even where the author has no objection."

My comments as an economist on Justice Breyer's statement above about the fact that royalties to be paid during the term extension period will mean higher prices that will potentially restrict a work's dissemination is that all prices for all goods and all services may be considered as limiting the use or consumption of the related goods and services.

A proper market place with proper marketable property rights is an efficient way to distribute goods and works and avoid the tragedy of the commons in expression. Free speech is about ideas. Having access to past copyrighted material for consumption or for use in the creation process of current creators is not much different from having access to office space, equipment, plumbers, electricians, managing consultants, artistic consultants, and so on, in the creation process. All of those resources or factors help creators produce new quality works.

The fact that creators must pay for those factors can only limit their capacity to produce more works. But nobody is claiming that creators should not be asked to pay their rent or their electricity or their food simply because they are creators. The royalties to be paid for the use of copyrighted works from the past is no different.

All those payments for factors in the creative processes are nothing to worry about, insofar as such payments, including royalties, are set or determined by competitive forces at competitive market levels. Since there are numerous copyrighted works from the past that are competing with each other in such an intense way, royalties can be considered competitive: more popular (in demand) works will command higher prices, less popular works lower prices.

\footnotetext{
${ }^{50}$ Eldred, supra note 17 at 248.
} 
In fact, all that an extended term prevents is the use, exploitation, or performance of works free of charge for a limited time. There is no argument that the price system cannot function in the same efficiency-wise way in the case of works as it functions for all kinds of goods and services.

If there is a reason for governments or for associations (collectives) to put copyrighted works in the public domain at life +50 , nothing prevents them from buying copyrights at their competitive market values at life +50 , possibly very small but occasionally still significant, and then verse the related copyrighted works in the public domain or assume copyright as rightsholders while marketing them at zero royalty cost.

Why should creators, their heirs, or the creative businesses whose investment made the copyrighted works possible be the ones financing the public domain? Nevertheless, there will be a time when copyrighted works will fall in the public domain, that is, a time when the costs of the public domain will fall below its benefits. For all the reasons above, life +50 is arguably not that time.

\section{APPENDIX C. Additional misconceptions about term extension}

Barker (2015) identifies and debunks some common myths about the economic effect of copyright term extensions for sound recordings, namely: term extensions mean heavy costs to consumers in royalty payments; royalty payments are sent out of the country; term extensions generate no additional incentive for creativity; and term extensions imply less creative material entering the public domain. ${ }^{51}$ The third and fourth myths were discussed above. Let me consider here the other two.

The fact that positive prices "hurt" the buying consumers is not by itself a reason for requiring zero prices. For the case of information assets, positive prices are essential to achieve a secondbest efficient allocation of resources to creative activities and industries even if marginal costs of use are zero, as I showed above. Claiming that term extension means additional costs for end consumers is an irrelevant truism.

The claim ignores other costs such as digital piracy, which involves hidden costs for consumers by hurting investments in the music industry, for instance in talent development and marketing (bringing to the market) works. It ignores also a free rider problem, which arises when a user prefers accessing the zero-cost public domain as compared to fostering the costly development of

\footnotetext{
${ }^{51}$ George Barker (2015), "Debunking common myths about the economic effect of copyright term extensions for sound recordings", SSRN, 29 April 2015. https://papers.ssrn.com/sol3/papers.cfm?abstract id=2600769. Barker claims that the underlying studies "were rejected by the UK Government and the EU Governments."
} 
new works and creativity. Such free-riding by record labels exploiting the public domain thereby reduces creativity. ${ }^{52}$

The claim assumes a copyright monopoly, forgetting that copyright is simply defining a property right that itself allows and fosters the emergence of a competitive market. Moreover, the copyright provides "protection for the creative expression of an idea, and not the underlying idea" and on so doing allows competition from close substitutes. The relevant model to use is monopolistic competition in which each seller is the only one selling his/her own brand or product but in competition with numerous other suppliers of differentiated products, many expressing the same or similar ideas. Indeed, competition can be harsh in monopolistic competition contexts.

The claim assumes deadweight costs due to restrictions on use of costless reproduction of works as, being non rival, past works are not subject to congestion. I addressed this issue above. I should stress again here that in the presence of network effects the uncontrolled (rational) misuse of public domain works may destroy their value to the detriment of all. As I showed above, the deadweight cost is a necessary and accepted cost of implementing a second-best efficient solution to copyright pricing.

The second myth is even more fatally flawed as it sidelines the main issue of creators' fair and equitable compensation and relies on a serious misunderstanding of international trade. Many critics of copyright term extensions use the argument that copyright royalties will leave the country and profit mainly foreigners. They compare the copyright payments made by nationals to foreigners and the copyright payments made by foreigners to nationals, that is, a comparison of imports and exports of copyrighted works (books and sound recordings in particular). This argument comes up whenever nationals buy more of some good or service from foreigners than they sell the same or similar good or service to foreigners. In so doing they fail to see the forest for the trees.

In a blog on January 20, 2020, Hugh Stephens wrote: 53 "This implies that only foreign rightsholders will benefit from the additional protection, which is just plain wrong. Not only will Canadian creators obtain the benefit of a longer period of copyright protection in Canada, they will gain an additional twenty-year protection in those countries that apply protection reciprocally. This is called the 'rule of the shorter term'."

Clearly, more royalties will be paid by Canadians to foreign rightsholders, but more royalties will also be paid by Canadians and foreigners to compensate Canadian creators as well as to help creation support companies to invest more in arts and culture. Moreover, when considering the

\footnotetext{
${ }^{52}$ The Stargrove Entertainment case, discussed in footnote 18 above, neatly illustrates the reality of this free rider problem.

${ }_{53} \mathrm{https}$ ://hughstephensblog.net/2020/01/20/the-new-nafta-uscma-cusma-and-copyright-term-extension-in-canadahow-and-when-will-canada-implement-its-commitment/
} 
copyright payment deficit if any that is incurred by a specific country, one should not ignore or forget the major value or utility (consumer surplus) nationals derive from accessing foreign books and sound recordings.

The international trade data for any country always show some sectors or some goods and services with a negative (deficit) balance and others with a positive (surplus) balance. No country has a positive trade balance for all goods and services nor should a country try to achieve such a state. Moreover, in addition to considering the sectoral and overall trade balance in goods and services (positive or negative), one must consider the balance of financial transactions (loans) and the balance foreign direct investments, that is, the balance of the country's direct investment abroad (by nationals) and foreign direct investment in the country (by foreigners). The sum makes up the balance of payments, whose "equilibrium pressures" determine and is determined by the exchange rate. In other words, the balance of copyright payments cannot be looked at in isolation, as it ignores other goods and services as well as the balance of financial transactions (loans and investments): all international transactions are glued to each through the exchange rate. The argument that copyright term extensions will generate copyright royalties that will leave the country and profit mainly to foreigners originates from a serious misunderstanding of international trade. It is a false argument. 